\title{
ТЕОРЕТИКО-МЕТОДОЛОГІЧНІ ОСНОВИ СІМЕЙНОГО КОНСУЛЬТУВАННЯ В РОБОТІ МЕДИЧНОЇ СЕСТРИ
}

\author{
I. М. Мельничук, О. І. Брик \\ ДВНЗ «Тернопільський державний медичний університет \\ імені І. Я. Горбачевського МОЗ Украӥни" \\ ННІ медсестринства
}

Розглянуто основні моделі сімейного консультування. Визначено сутність психодинамічної моделі

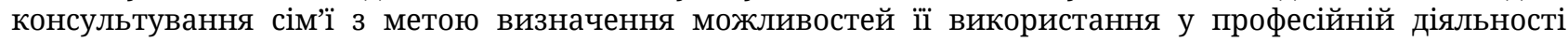
медичної сестри.

\section{THEORETICAL AND METHODOLOGICAL BACKGROUND OF FAMILY CONSULTING IN NURSE'S ACTIVITY}

\author{
I. M. Melnychuk, O. I. Bryk \\ I. Horbachevsky Ternopil State Medical University \\ Nursing School
}

The basic models of family consulting are discussed. The essence of psychodynamic model of family consulting is justified to find out the possibilities of using them in nurse's professional activity.

Вступ. Глибокі соціально-політичні й економічні зміни в нашій державі, зростання політичних та соціальних колізій, перегляд цінностей у суспільстві створили несприятливі умови для конструктивного розвитку сім'ї, що потребує перегляду концептуальних підходів до роботи не лише педагогів і соціальних працівників, а й фахівців медичної сфери, зокрема, медичних сестер. Консультативна допомога сім'ї спроможна запропонувати технології для пристосування ії членів до кризової ситуації, пов'язаної з хворобами, потребою лікування та наслідків впливу несприятливих обставин життя.

Характер дослідження визначив необхідність звернення до наукових праць, предметом яких було вивчення особливостей роботи з сім'ями, їх консультування та вироблення технологій роботи 3 проблемними сім'ями [1]. Насамперед це наукові дослідження представників київської школи українських дослідників А. Капської, З. Зайцевої, І. Трухіна та ін. Методологічне значення для даного дослідження мало наукове узагальнення проблем психолого-педагогічного консультування (О. Безпалько, Р. Вайнола,

() І. М. Мельничук, О. І. Брик, 2017
О. Кузьменко, І. Пінчук, Н. Пихтіна та ін.). Однак науковці не приділяли належної уваги ролі медичних сестер у сімейному консультуванні [2], що є невирішеними раніше частинами загальної проблеми, яким присвячується стаття.

Основна частина. 3 метою визначення напрямів сімейного консультування в роботі медичної сестри розглянемо основні моделі цього феномена, що й окреслено основними цілями написання статті.

Сімейне консультування набуло широкого застосування в середині 70-х років XX ст. Узагальнення практичних напрацювань здійснили Р. Шерман і Н. Фредман [3]. Науковці розробили посібник «Структуровані техніки сімейної та подружньої терапії» як зручне джерело, до якого могли 6 звернутися практики (педагоги, психологи, соціальні та медичні працівники), дослідники, студенти з метою отримання вичерпної інформації стосовно використання у професійній діяльності оптимальних та ефективних технік та інструментів сімейної терапії. Авторами виокремлено певні моделі сімейного консультування, які доцільно використовувати в професійній роботі медичних сестер. Це психодинамічна модель консультування 
сім'ї; модель біхевіористичного консультування сім'ї; структурна модель консультування сім'і; модель комунікаційного консультування сім'ї.

У сучасних фахівців, які працюють у цьому напрямі, найвизнанішою $є$ психодинамічна модель консультування сім'ї. Жодна з теорій не отримала такого широкого розповсюдження і не знайшла такого широкого застосування, як психоаналіз. Базові поняття і принципи (наприклад, Едипів комплекс) цієї теорії тісно пов'язані зі стосунками у сім'ї. Модель психологічного консультування сім'ї, котра спирається на психодинамічну теорію, розробив М. Бовен.

Зазначимо, що основні положення М. Бовена полягають у тому, що сім'я - це не лише невелика група людей, котра проживає у спільному будинку, а й емоційна система, в котру входять всі члени сім'ї (і живі, i померлі, і ті, які не проживають із сім'єю з тих чи інших причин, наприклад, внаслідок тривалого лікування). Ця емоційна система існує в теперішній сім'ї (навіть у тому випадку, якщо членів сім'ї вже немає у даній реальності або вони роз'єднані простором). Емоційна система сім'ї являє собою трансгенераційний феномен, вона поєднує представників усіх попередніх поколінь. Цю ознаку необхідно враховувати медичним сестрам, які вступають в бесіду з пацієнтами та їхніми родичами.

Емоційна система сім'i, котру образно можна назвати спільним «я» сім'ї, без сумніву впливає на підростаюче покоління. Серед них можна побачити два типи особистості: незалежну, диференційовану від сім'ї та підвладну, залежну, «сплавлену» з сім'єю. На думку М. Бовена, процес диференціації співпадає з процесом становлення, дозрівання особистості. На початковому етапі усвідомлюється відокремлення себе від інших, на наступних - більш чітке відокремлення своїх потреб, відчуттів, мислення, тобто здатність осмислювати чуттєві (емоційні) процеси окремо від інтелектуальних. Тому диференційованим особистостям притаманна більш швидка реакція, вони краще пристосовуються, більш об'єктивно оцінюють свої та чужі емоції та потреби, знаходяться на більш високому рівні самостійності. Судження будують на основі мисленнєвих операцій, а в своїх діях керуються аргументованими думками, або чіткими принципами, схильні обговорювати альтернативи вибору, що сприяє налагодженню контактів на рівні «родичі пацієнтів - медичний персонал» чи «пацієнт - медичний персонал». У таких людей міцне, цілісне внутрішнє «Я», вони здатні зрозуміти власні почуття. Особистості протилежного типу - це недиференційовані, залежні, за словами М. Бовена, люди «сплаву». Вони регітні, керуються більше емоціями, ніж принципами мислення. Крім того, не здатні відрізнити свої емоції від потреб або інтелектуальних рішень, що ускладнює організацію конструктивної взаємодії медичних працівників з пацієнтами та їхніми родичами.

Проблеми сім'ї М. Бовен пояснює, виходячи 3 інтергенераційної гіпотези. Суть даної гіпотези полягає в тому, що люди, котрі виросли в так званих сім'ях «сплаву» і не відокремились від них, мають схильність створювати сім'ї з такими ж людьми. «Двоє недиференційованих, - зазначає М. Бовен, - шукають один одного» [4]. Результат подібного шлюбу - хибне емоційне відокремлення від батьківських сімей та непродуктивна передача емоційних процесів, котрі проходили в попередніх поколіннях, у майбутнє. Типова проблема подібних сімей - всі ї̈ члени вимагають один від одного постійних почуттів, стабільних стосунків та світовідчуття. На прикладі це можна охарактеризувати так: кожен із членів сім'і у складній ситуації перебування одного з них у лікувальному закладі, або маючи проблеми зі здоров'ям, очікує рішення, або підтвердження почуттів від інших, що породжує нестійку, нестабільну емоційну систему. Та, в свою чергу, стає причиною виникнення нових фізичних та психічних розладів, психосоматичних захворювань, що провокують виникнення сімейних конфліктів.

Поведінка сім'ї під дією постійного або сильного стресу, викликаного захворюванням одного з членів сім'i, має свої закономірності. Так, М. Бовен характеризує їх за допомогою поняття тріангуляції. Він вказує, що сімейна пара або будь-яка інша діада стабільна до тих пір, поки не переживає стрес (неспокій, страх і тому подібне). Коли стрес починає перевершувати можливості діади протистояти йому, перевищує рівень толерантного ставлення до стресу, в проблеми діади входить третя сторона (в сім'ях у подружні проблеми зазвичай втягуються діти), оскільки існує надія, що в конфлікті третя сторона підтримає його або їі. Якщо стрес особливо сильний, у проблеми втягується все більше третіх сторін, тому виникає все більше тріангуляцій. У лікувальному закладі такою стороною може бути медична сестра, яка може зменшити напруженість у стресовій ситуації. М. Бовен зауважує, що поодинці елементи тріангуляційного процесу не є шкідливими, психологічні проблеми сім'і ускладнює їх сукупність.

Все вищезазначене дає М. Бовену можливість оригінально сформулювати концепцію про здоров'я 
і норму й разом з тим окреслити цілі психологічного консультування сім'і, методикою якого має опанувати медична сестра. 3 точки зору науковця, визначальне значення для оптимального функціонування особистості в соціумі та сім'ї $\epsilon$ необхідність усвідомлення нею своїх потреб, відокремлення потреб і рішень від емоцій. Хоча під впливом хронічного і сильного стресу (наприклад, тривалої і тяжкої хвороби когось із членів сім'і) особистість може витіснятися з оптимального функціонування і відтак втратити здатність керуватися інтелектуальними принципами. Тоді вона свої драматичні емоції починає ототожнювати з реальністю, заперечує взаємозалежність причин і наслідків. Подібні ситуації медичні сестри покликані також враховувати у спілкуванні з родичами пацієнтів та самими пацієнтами, які тривалий час перебувають на лікуванні.

Медична сестра повинна допомогти членам сім'ї в умовах дії стресу адекватно на нього реагувати, вирішувати і вчитись вирішувати породжувані стресом проблеми. Більше того, справлятись з ними не шаблонно, а з орієнтацією на особистості та потреби конкретних людей (своїх близьких).

Як зазначає М. Бовен, консультування повинно базуватися на основі спостереження емоційних процесів, котрі проявляються в сім'ї. Спостереження розуміється тут як повідомлення необхідної інформації медичній сестрі, відверта розповідь про себе, а ціленаправлена допомога - як її поради, рекомендації. Однак низьку ефективність порад М. Бовен лаконічно пояснює так: «Невідкладна корисність викликає безсилля» [4]. Це означає, що сім'я, отримавши навіть дуже корисні поради, котрі вони не вміють реалізувати, розчаровуються в консультації і стверджуються в установці: взаємини в їхній сім'ї не можуть змінитися на краще, тому знову повертаються до стереотипів непродуктивної поведінки.

\section{СПИСОК ЛІТЕРАТУРИ}

1. Мельничук І. М. Професійна робота в школі як напрям попередження трудової експлуатації дітей : навч.метод. посіб. / І. М. Мельничук, Л. М. Романишина, Ю. М. Лицур ; за заг. ред. К. Б. Левченко, І. М. Трубавіної. К. : Юрисконсульт. - 2006-2007. - 334 с.

2. Мельничук І. М. Теоретичні основи професійної підготовки фахівців медсестринства / І. М. Мельничук //
Реалізувати на перший погляд просте завдання - спостереження за сім'єю може здійснити лише професійно підготовлений фахівець - активний, дружелюбний, невимушений, спокійний, соціалізований, об'єктивний, не обтяжений невирішеними емоційними проблемами власної сім'ї, який в змозі впливати на емоційну систему сім'ї, яку консультує, i відгородити себе від їі впливу. Ніякі спеціальні методи чи психологічні техніки в даному випадку не мають визначальної ваги. Спостереження та вивчення сім'ї невід'ємне від впливу на неї, оскільки пізнавати сім'ю і не впливати на неї не можливо. Тому медична сестра при спостереженні, вивченні сім'і пацієнта повинна поводити себе як незалежна, диференційована особистість, тобто остерігатися, щоб не бути втягнутим у тріангуляційні процеси, дотримуватись об'єктивності.

Висновки. Медична сестра покликана опанувати методики використання різних моделей консультування сім'ї, в якої виникли проблеми зі здоров'ям. Основою психодинамічної моделі консультування сім'і $\epsilon$ той факт, що медична сестра не бере участі в емоційній системі сім'і, що стабілізує взаємини і сприяє більш інтенсивному спілкуванню між ними. Запропоновані науковцями теоретичні принципи консультування сім'ї підкріплені практикою і достатньо розроблені. Вони дозволяють передбачити перспективи сім'і, яка стикається з необхідністю звертатися до медичного персоналу з питань збереження здоров'я та лікування, дають змогу виявити причини сімейних проблем у таких випадках, пояснюють минуле і допомагають контролювати теперішнє.

Перспективи подальших наукових досліджень вбачаємо у розробці спеціальних тренінгових завдань для підготовки медичних сестер до сімейного консультування.

Науковий вісник Чернівецького університету. Випуск 749. Педагогіка та психологія. - 2015. - Вип. 749. - С. 90-98.

3. Шерман Р. Структурированные техники семейной и супружеской терапии / Р. Шерман, Н. Фредман. - М., 1997. - 347 c.

4. Эйдемиллер Э. Г. Психология и психотерапия семьи / э. Г. Эйдемиллер, В. В. Юстицкис. - СПб. : Питер, 1999. - 487 с. 